\title{
Screening of Wetland Plants Subjected to Stress From Polychlorinated Biphenyls Contaminated Soils
}

Foqia Khalid ( $\square$ foqiakhalid38@gmail.com )

University of the Punjab Quaid-i-Azam Campus: University of the Punjab

Muhammad Zaffar Hashmi

COMSATS University Islamabad

Nadia Jamil

University of the Punjab Quaid-i-Azam Campus: University of the Punjab

Abdul Qadir

University of the Punjab Quaid-i-Azam Campus: University of the Punjab

\section{Research Article}

Keywords: Polychlorinated biphenyls, Phytoremediation, Wetland plant, Biodegradation, Electronic waste, Dechlorination

Posted Date: March 10th, 2021

DOI: https://doi.org/10.21203/rs.3.rs-207623/v1

License: (1) (1) This work is licensed under a Creative Commons Attribution 4.0 International License. Read Full License 


\section{Abstract}

Soil pollution due to electric and electronic waste (e-waste) has become a major problem that is degrading environment and drawing worldwide attention. PCBs are widespread and have potential health risk so their removal from the environment has become an international priority. Phytoremediation is considered as highly accepted and good method for treatment of contaminated soils. Current study was conducted to investigate the abilities of several promising wetland plants to degrade and dechlorinate PCBs and demonstrate their advantages in disappearance of polychlorinated biphenyls. The soils samples were collected from PCB-contaminated sites at Layyari, Karachi Pakistan. Under both floody and dry condition plants including Alternanthera sessilis (L.), Bacopa moneiri (L.) Pennell, Centella asiatica (L.) Urban, Juncus articulatus L., Cyperus arenarius Retz were grown. For dechlorination of PCBs three treatments were set up in a fully randomized layout of greenhouse pots. Soil from those pots was extracted and further analyzed by Gas chromatography equipped with a 63Ni electron capture detector. The detection limits of PCBs ranged from 0.009 to $0.082 \mu \mathrm{g} / \mathrm{kg}$. In total PCBs degradation ratio was $22.44 \%$ while in high chlorinated PCBs almost $15.26 \%$ of the high polychlorinated biphenyls were removed from the soil after 2 month in the wetland planted soil, while only $4.64 \%$ was removed in the drowned control and $6.54 \%$ in the unplanted control. Present study concludes that this method only has high efficiency in removal of low chlorinated biphenyls, while low efficiency even nothing in removal of high components.

\section{Introduction}

Soil contamination due to disposal of electric and electronic waste and its informal recycling has paid significant attention in these years (Shen et al. 2009). Many toxic pollutants used in formation of electric appliances i.e. polybrominated diphenyl ethers used in used in circuit boards as flame retardants and polychlorinated biphenyls in transformers and capacitors, can be released during recycling process (Liu et al. 2008). In production of total municipal waste share of e-waste is about $5 \%$. Global e-waste generation was 53.6 million tons in 2019 and expected to be 74 Million tons by 2030 while in 2050 it might reach 120 Million tons (Forti et al. 2020; World Economic Forum, 2019). Specifically, domestic appliances i.e. telecommunications, washing machines, TVs and computers are major portion of e-waste created worldwide (Akram et al. 2019). In developing countries, Pakistan has recognized as main importer of electronic waste that increases the domestic electrical waste generation. Now Karachi is considered as one of most populated, industrialized and urbanized coastal cities in world. Karachi city is surrounded by various industrial activities and having two main sea ports through which electrical waste is being imported from different countries then its valuable parts are separated and remaining is dispose off. While during recycling of e-waste main informal practice is burning of electrical waste in open air, its melting, acid baths and dismantling. Non recyclable waste is dispose off in water bodies or landfills. (Iqbal et al. 2017) In moderate to low income countries about $90 \%$ of electrical waste is handled by informal ways and un-proficient workers (Pathak et al. 2019). 
The methods used in e-waste recycling process are often primitive, without appropriate amenities to save human health and environment (Wong et al. 2007). Contamination of soil, water, air and sediments occur due to extensive PCBs emission that is Contamination with PCBs still occurs and is considerable because of potential toxicity and bioaccumulation for wildlife and humans (Cogliano 1998; Zhao et al. 2006). For better control and recycling of e-waste in environmentally sound way a better long term management practice is required (Takahashi et al. 2017) A huge amount of POPS (Persistent organic pollutants) are entering in the environment due to human activities, maximum of them have ability to bioaccumulate in food chain, persistent and pose health risk to humans and wildlife (Scheringer et al. 2012)

It is top priority at global scale to eliminate PCBs from environment to reduce its potential health effects (Ding et al. 2009). Bioremediation using microbes considers the best alternative method to save environment at reduced cost and less environmental impacts. Several fungal species especially white rot basidiomycetes, degrade PCBs effectively than others (Perrigon et al. 2019) Prevailing chemical and physical procedures for soil remediation, oftenly generate secondary waste compared to that phytoremediation is cost effective process and cause minimum disturbance in environment (Doni et al. 2012). It is use of plant metabolism (phytodegradation, phytoextraction \& phytovolatilization) and microbes directly linked with root surface area to rhizodegrade pollutants from the surroundings (Van et al. 2010). Plants belong to cucurbitaceae family uptake PCBs from soil and it has been successfully tested (Vergani et al. 2017) Plants reduce toxicity by absorbing PCBs through their roots and used them as energy source and transform them by various metabolic pathways. Plants belong to genera Medicago, Panicum, Festuca, Brassica and Nicotiana have been evaluated in different studies of phytoremediation. Although, Plants have enough capacity for the removal of PCBs but they also have been shown to prevent plant growth that severely effect phytoremediation (Pino et al. 2019). It can be tested in area that supports plant growth and it can easily be accepted both socially and aesthetically. Phytoremediation technology that focused on PCBs has been extensively reviewed in the literatures (Asai et al. 2002; Chekol et al. 2004; Chu et al. 2006a; Xu et al. 2010; Chen tu et al. 2011; Tu et al. 2011; Kurzawova et al. 2012; Meggo et al. 2013; Vergani et al. 2017; Pino et al. 2019). Phytoremediation is directly linked to rhizodegradation of PCBs by releasing different compounds through roots of various plant species (Musilova et al. 2016), comprising Festuca arundinacea, Medicago sativa and Brassica napus, enhance microbes responsible for PCB degradation and change the soil-microbes community structure (Teng et al. 2016). Microbial activity and biomass increases due to release of metabolites in rhizosphere thus in rhizosphere plant roots interact with several microbes i.e. plant growth promotors (PGP), fungi and endophytic bacteria (Di Lenola et al. 2018). Despite the persistency of high PCBs, their degradation and elimination continuous by microbes naturally (Emma et al. 2002) due to plant growth at e-waste contaminated areas microbial potential to degrade PCBs enhance as due to vegetation organic carbon increases in soil and plantation of deep rooted species helps microbes to degrade PCBs (Campanella et al. 2002). In several studies it was notices that plants contribute major in PCBs degradation but relevant models are rare. Many papers focus on tissues and cell of plants (Estime and Rier Jr 2001; Mackova et al. 1997). In order to improve absorption capacity of plant and extent application scope of phytoremediation, some researchers start to take transgenic method into consideration, which greatly promote removal of 
xenobiotic pollutants (Abhilash et al. 2009; Eapen et al. 2007; Van Aken et al. 2010). But the safety of this method must be paid attention in detail, we cannot't be at risk of it.

However, on one hand, the aerobic PCBs degradation by using plants usually degrade those PCB congeners which are slightly chlorinated such as five or few more congeners (Wiegel and Wu 2000). Highchlorinated congeners are quite recalcitrant to microbial metabolism for aerobic degradation. On the other hand, due to hydrophobic nature of PCBs they highly adsorb on soil organic matter but in case of soil-water situation where microbes are mostly available PCBs cannot be dissolved and degraded (Providenti et al. 1993). Plants usually have less catabolic enzymes important to attain metabolism for recalcitrant organic compounds result in slow elimination and inadequate degradation (Eapen et al. 2007). Soil pollution has become a major problem that is degrading environment and drawing worldwide attention. Phytoremediation is considered as highly accepted and good method for treatment of contaminated soils. Various approaches have been used worldwide to increase efficiency of phytoremediation (Song et al. 2019). Phytoremediation have some limitations that avoid large scale experimentation in field (JERALD et al. 1995; Salt et al. 1998).In view of an inconvenient disadvantage of phytoremediation, we must make clear it whether wetland plants can solve this question, which give us more widespread thought and focus. Wetland plants absorb water more efficiently than non-wetland plants but transpiring plant species negatively affect PCBs degradation (Smith et al. 2008). It's been understood from around 40 years that wetland plants and submerged aquatic macrophytes such as sea grasses are capable to oxygenate its roots to save themselves from negative effects of phytotoxins such as $\mathrm{H}_{2} \mathrm{~S}, \mathrm{Mn}^{2+}$ and $\mathrm{Fe}^{2+}$ that produce in anaerobic situation (Huesemann et al. 2009). Meanwhile, wetland plants owed greater biomass and roots system created a great volume of active rhizosphere per surface area compared to other plants, which lead to frequent microbial activities, such as degradation of organic matters (Brix 1987; Cheng et al. 2009; Yang et al. 2007). What's more, it can provide different habitats for organism and better removal qualification to organics under the wetland conditions, on one hand, there was some anaerobic environment and on the other hand, contrary to that. As a result, high chlorinated PCBs were more soluble afterward few early reductive dechlorination stages, and hence more bioavailable then degraded soon afterwards (Imfeld et al. 2009). Consequently, the wetland plants can be selected with more degrading capacity at contaminated sites and in production of multi wetland plant species.

The aim of this research was to examine the abilities of several promising wetland plants to degrade and dechlorinate PCBs and demonstrate their advantages in disappearance of polychlorinated biphenyls as compared to phytoremediation only contained certain terrestrial plant. Make an attempt for screening high synthetically efficient wetland plant in PCBs degradation and dechlorination. Mostly, the present research can give an excellent trial for engineering application of PCBs polluted soils remediation.

\section{Materials And Methods}

\subsection{Site details and soil properties}


The soils used in this study were collected from PCB-contaminated sites at Layyari, Karachi Pakistan. Around world, Karachi is main dumping ground of electronic waste. Mostly E-waste is being dumped with municipal waste, open burning of e-waste is common practice due to which many organic pollutants release and cause serious health effects. In Layyari, e-waste segregation is being done by the workers including children and women, not knowing the after effects due to informal handling and continuous exposure. Due to poverty in recessive areas of Karachi it's their main source of income and after segregation copper is being separated remaining material commonly burn without adopting proper health and safety measures. After collecting soils from e-waste contaminated sites it was dried and sieved through $2 \mathrm{~mm}$ sieve to remove roots and stones. Original PCBs concentration was $100 \mathrm{mg} / \mathrm{kg}$ that was further reduced after planting treatments in both floody and dry conditions. Soil texture was clay loam having pH $6.46\left(\mathrm{H}_{2} \mathrm{O} 1: 1\right), 4.19 \mathrm{~g} \mathrm{~kg}^{-1}$ total $\mathrm{N}, 63.8 \mathrm{~g} \mathrm{~kg}-1$ organic matter, $1.96 \mathrm{~g} \mathrm{~kg}^{-1}$ total $\mathrm{P}, 116 \mathrm{mg}$ $\mathrm{kg}^{-1}$ exchangeable $\mathrm{P}, 370 \mathrm{mg} \mathrm{kg}^{-1}$ exchangeable $\mathrm{K}$ (dry weight basis) and $22.2 \mathrm{~g} \mathrm{~kg}^{-1}$ total $\mathrm{K}$ and (Soil properties: moisture content, organic matter, $\mathrm{N}, \mathrm{P}, \mathrm{K}, \mathrm{pH}: 6.5$, soil texture: clay loam and initial concentration).

\subsection{Wetland plant selection}

Following Pakistani plants were selected: Alternanthera sessilis (L.), Bacopa moneiri (L.) Pennell, Centella asiatica (L.) Urban, Juncus articulatus L., Cyperus arenarius Retz. Two conditions dry and floody were maintained.

\subsection{Experimental layout}

Immediately before bioremediation treatments, all polluted soil taken from 0-30 cm was mixed, putting forward residual branches and leaves, homogenized and passed through $2 \mathrm{~mm}$ sieve, the soil sample attained (initial soil marked T0) was examined in triplicate to obtain an initial soil categorization (described in site details and soil properties).

There were three treatments set up in a randomized block design: flooding and dry soil without planting as controls, planted soil with wetland plant as test. The three treatments were set up in a fully randomized layout of greenhouse pots. Wetland plant grown in pots of height $26 \mathrm{~cm}$ contained $5 \mathrm{~kg}$ polluted soil. For flood and plant treatments, it was critical important to ensure the water level upon soil surface $5 \mathrm{~cm}$, which served as standard line in advance and replenishing water to the line daily. Contrary to flooding soil, dry treatment was so simple that you only spilled little water to make superficial soil moist. At last, to balance oxidation-reduction potential in soil and obtain stable and beneficial ecosystem for microbial community growth, placing the soil after pretreatment through getting rid of, grinding and sieve methods after flooding one week.

At the beginning of experiment, taking 0 moment samples served as initial concentration of polychlorinated biphenyls to estimate bioremediation efficiency of wetland plants. Afterwards, there was a job which took soil samples used five points method through self-made tools, four near corners and one 
in center, monthly. To guarantee good growth conditions for wetland plants, there were essential work monitoring greenhouse temperature and observing plant growth vigor daily.

\subsection{Analytical methods \\ 2.4.1 Chemicals}

\section{Pot cultural experiment}

For it the purified water added into the polluted soil for maintain flooding depth and soil moist was purchased from certain pure water company.

\section{Soil sample pretreatment}

For pretreatment all solvents used (acetone, hexane, concentrated sulphuric acid) were of analytical grade (Sinopharm Chemical Reagent Co., Ltd, China). PCB209 were obtained from AccuStandard, China. Sodium sulfate (granular, anhydrous) and florisil were purified by heating at $450^{\circ} \mathrm{C}$ for $8 \mathrm{~h}$ in a shallow metallic enamel tray.

\section{Analysis}

For analysis standard reference material arocher1254 was used that was also purchased from AccuStandard, China.

\subsubsection{Analysis of PCBs in soil and wetland plant}

Soil was weighed and five grams of sample was taken and extracted three times by the ultrasound extraction method in a centrifuge glass tube with $70 \mathrm{ml}$ combination of hexane-acetone $(1: 1, \mathrm{v} / \mathrm{v})$. Gradient was $30 \mathrm{ml}, 20 \mathrm{ml}$, and $20 \mathrm{ml}$, respectively. Time was 5 minutes. The solution after extraction was concentrated by rotary evaporator by $1 \mathrm{ml}$, diluted by $6 \mathrm{ml}$-hexane and washed by concentrated sulfuric acid to $8 \mathrm{ml}$. The mixture solution of shaking up and down repeatedly were centrifuged 5 minutes and the extracted solvent passed through anhydrous sodium sulfate and florisil column and wash with $100 \mathrm{ml}$ mixture of hexane-acetone $(9: 1, \mathrm{v} / \mathrm{v})$. The extracted solutions were concentrated to about $1 \mathrm{ml}$ in a rotary evaporator again, dissolved in $6 \mathrm{ml}$ hexane in a nitrogen blowpipe and concentrated to $1 \mathrm{ml}$ using a Pressure Blowing Concentrator (Ding et al. 2009). The concentrations of PCB congeners were measured by a gas chromatograph equipped with a 63Ni electron capture detector (Agilent 6890, United States) (Shen et al. 2009). All procedures were performed under strict quality control to meet USEPA requirements. Decachlorobiphenyl (PCB209) was spiked to detect recoveries. The range of recoveries for PCB determination was $80-110 \%$. In current study, the final values of the target compounds in soils were not corrected with recoveries. The detection limits ranged from 0.009 to $0.082 \mu \mathrm{g} / \mathrm{kg}$.

\subsection{Data analysis}


Statistical analyses was done, including correlation among variables and mean values were calculated by using SPSS 13.0, The Microsoft excels 2007 and origin 75 was used to present the results in the form of bar graph. The percentage of removal efficiency of different wetland plants were calculated with the formula.

\section{Results}

\subsection{Degradation efficiency of total polychlorinated biphenyls}

Figure 1 demonstrates the removal rate of wetland plants includes Alternanthera sessilis (L.) (AS), Bacopa moneiri (L.) Pennell (BMP), Centella asiatica (L.) Urban (CAU), Juncus articulatus L. (JA), Cyperus arenarius Retz (CAR), and controls to all PCBs using pot culture after a standard 2 month incubation period in both dry and floody conditions.

After screening experiment of 2-months, PCBs concentration was less in wetland planted pots as compared to unplanted controlled treatment. The amount of PCBs reduced slightly in wetland plants and unplanted treatments, drowned and dry treatments. In terms of controls effecting on removal of PCBs, control dry have more efficiency in removal as compared to the flood control. Bioavailability of PCBs is strongly affected by physicochemical properties of soil so soil properties have been evaluated before initiating experimental work (Vergani et al. 2017).

\subsection{Dechlorination of high chlorinated biphenyls}

As shown in Fig. 2 for the degradation or dechlorination efficiency value of PCBs which contained 5-7 chloride atoms in biphenyls molecular, in general, the concentrations of high chlorinated PCBs reduced speedily and more degradation was observed in the wetland plants than in unplanted treatments. The results showed that far from total removal rates of high chlorinated in planted soils were much higher than in unplanted soils.

\subsection{Degradation of low chlorinated biphenyls}

The mean values of PCB homologues under various treatments in the soils are shown in Fig. 1.

For the low chlorinated congeners of PCBs, wetland plants contained $27.31 \%$ have good removal efficiency in degradation of PCBs as compared to $9.27 \%$ and $6.54 \%$ in the unplanted control.

In terms of dry and flood controls, dry has a better efficiency than flood treatment for degradation of low chlorinated PCBs. The $9.27 \%$ and $6.54 \%$ of the initial PCBs were removed from unplanted treatments, respectively.

\section{Discussions}


As for removal of persistent organic pollutants, most economic and widely used technology is phytoremediation, which brought up a great deal of focus from domestic and overseas. The mechanism researcher based mostly contained plant root absorption, transformation, and volatilization or metabolized by plant cells and microbial degradation. PCBs phytoremediation directly linked with process of rhizodegradation and associated with many compounds that released by roots of various plant species (Musilova et al. 2016), including Festuca arundinacea, Brassica napus and Medicago sativa. These species increases population of microorganisms responsible for PCB degradation and can which can change community structure of soil microbes (Teng et al. 2016). Although the removal efficiency is good, it is insufficient to dislodge high chlorinated pollutants, such as PCBs. We think the wetland plants can solve this problem. To our astonishment, Most of the pioneers focused their research center on removal of nutrition, such as TN, TP and others through various wetland plants which contained the fibrous-root plants and rhizomatic-root plants (Cheng et al. 2009; Stottmeister et al. 2003). There are some proves about removal of nutrition and heavy metals using the wetland plants to treat waste water (Wang et al. 2002). In recent study conducted by Salimizadeh et al. 2020 phytoremediation was done by Alternanthera sessilis $L$. and 17 PCB congeners were selected combination of low and high chlorinated congeners. Degradation efficiency of PCBs was $21.4 \%$.

Research relevant to degradation of organic compounds in wetland species is still in beginning. (Imfeld et al. 2009). In a previous study conducted by Chu et al. revealed that solution of two wetland plants, rice and common reed, gathered and converted PCBs and DDT mixed with culture solution (Chu et al. 2006b). Meanwhile, they also paid close attention to the enzyme systems of the wetland plants, $P$. australis and $O$. sativa, to make it clear that which was much more effective to transform and degrade organic pollutants (Chu et al., 2006a). In the present study the wetland plants (Alternanthera sessilis (L.) (AS), Bacopa moneiri (L.) Pennell (BMP), Centella asiatica (L.) Urban (CAU), Juncus articulatus L. (JA), Cyperus arenarius Retz (CAR)) were selected to sort out the removal efficiency of the PCBs contaminated soil starting from the lower chlorinated to higher chlorinate and PCBs in combined form in soil. Soils having maximum concentration of clay and organic matter absorb PCBs molecules strongly by complicating plant uptake and microbial degradation (Vitale et al. 2018). In a study by Mbemba et al. Cyperus papyrus L. can be used for removal for organic pollutants (Mbemba et al. 2019)

In rhizosphere microbial activity and biomass increased by releasing metabolites by plant roots because rhizosphere is that thickly populated zone where plant roots directly interact with the microorganisms, such as fungi, plant growth promoters (PGP), and endophytic bacteria (Lenola et al. 2018). Previous research has described that the type of plant has also impact on population of soil microbes (Terzaghi et al. 2018). This is strongly related to root exudates composition that changes with change in plant species and also with ability of plant to develop links with microorganisms i.e. Mycorrhizas (lonescu et al. 2009).

All PCBs attenuation is results of interaction among high-chlorinated PCBs in Dechlorination, low PCBs in degradation and plant absorbing PCBs self-attenuation and PCBs volatilization, which is also important target in our project that will be screening of best wetland plant that exhibited good removal efficiency in 
total PCBs. The present study is novel and first time describes the PCBs removal efficiency from the wetland plant, which combine plant remediation with anaerobic degradation using microbial function.

Each congener's degradation directly depends on its substitution pattern and number of chlorines present. Few researches has described the degradation of single congener existed in Aroclor mix., some others have calculated PCBs degradation according to fall in total Aroclor concentration which does not permit estimation of each congener removal. Moreover, the rate of degradation is different for each congener and depends mainly on the pattern of chlorination and amount of chlorine in molecule (Paasivirta and Sinkkonen 2009). We found that the amount of total PCBs, not depending on degree of chlorination, was decreased to maximum extent in wetland than in unplanted treatment. According to the research of Stottmeister about effects of plants and microorganisms in wetland on organic chemicals, in wetlands, the main role in the transformation and mineralization of organic pollutants is played not by plants but by microorganisms (Stottmeister et al. 2003). The measurement result of plant samples shows that in this research, PCBs concentration in shoots and roots of wetland plant are few. The experiment whose result showed only $0.43 \%$ of extractable total soil PCBs was detected in the whole plant Ding et al., 2011 supports it (Ding et al. 2011). Consequently, we mainly explain reason why the wetland plants are better than others from the point of view of microorganism.

Rice and reed plants have been considered to takeup maximum concentration of PCBs (Chu et al. 2006b). Uptake of contaminants done by various processes i.e. phytoaccumulation, phytodegradation and phytovolatalization whereas, metabolic conversion of organic pollutants is significantly more appropriate for PCBs removal.

This would show the processes except microbial degradation in aerobic condition as a result of aeration in root zone accountable to reduce PCBs in the planted soils. Microbial degradation of PCBs in plant roots can be increased by organic carbon supply, inducing PCBs catabolic pathway, discharge of bio surfactants in soil and diffusion of oxygen in soil (Meggo et al. 2013). So, the contaminants that release in rhizosphere by plant roots have considerable effect on degradation of organic contaminants by microbes (Jha et al. 2015)

Data from this potted trial did show significantly that there was not all lesser amount of PCBs from wetland-planted treatments as compared to unplanted soils in 60 days of experiment for remediation purpose (see Fig. 3). The removal of PCBs in controlled treatments may be due to self-degradation and volatilization of compounds in soil media (Mackova et al. 2009), which point out considerable decline in PCB concentration i.e. $470 \mu \mathrm{g} / \mathrm{g}$ concentration in 1999, decreased and average amount was $330 \mu \mathrm{g} / \mathrm{g}$ in 2003 and $200 \mu \mathrm{g} / \mathrm{g}$ was calculated in 2005. Meanwhile, it is demonstrated that current study plays a more important role in the degradation of PCBs from soil. These results finalized the observations of Chu et al. (2006) and Kei (2004) in hydroponic culture experiment that wetland plant does facilitate the depletion of soil PCBs (Chu et al. 2006b; Kei 2004). Lower PCBs congeners may transfer through plants, deposited in lignin or plant cell wall, and then might be degraded inside plant tissues or transpiration loss (Van Aken et al. 2010). Furthermore, native soil microbes have vital role in bioremediation of PCBs 
aerobically with few chlorines (Mackova et al. 2010). Considered what we know about accumulation of PCBs by using plant methods, they mainly utilized plant roots to absorb PCBs from contaminated soils, transported to stem and leaves, which complete the complex processes(Liu and Schnoor 2008; Pavlikova et al. 2007; Zeeb et al. 2006). However, in present work, there were minimal PCBs existed in plant, which make the decrease processes more clear. Except volatilization, microorganism degradation played critical role. The wetland plant roots possessed the function of tight oxygen to create aerobic situation and low PCBs concentration, thus increase the aerobic degradation of low PCBs congeners (Armstrong et al. 1990; Pezeshki 2001; Wiebner et al. 2005). In aerobic degradation, oxygen released around root area or rhizosphere, specifically root tips surroundings and upon young laterals (Armstrong et al. 1990). Furthermore, plants release a vast range of organic matter via roots in rhizosphere (Rovira 1959). Bioavailability of contaminants could be enhanced through root exudates that provide extra substrates for co-metabolic degradation and modification in soil to get it more feasible for microbial conversion (Molnar et al. 2005; Singer et al. 2003). Additionally, this type of variety added in removal of contaminants from polluted soils as organic pollutants degradation may involve different organisms having unique enzymes system (Meharg and Cairney 2000).

The accurate opportunity for biodegradation of perchloroethylene, maximum chlorinated congeners and hexachlorobenzene is only reductive dechlorination (Wischnak and Müller 2008). Due to diverse redox conditions, prevailing because of halophyte roots that donate oxygen, a wetland is basically a metabolically strong technical ecosystem (Stottmeister et al. 2003). In present work, there was a longterm drowned environment under different wetland plants, which arose up anaerobic conditions; although there were many plant roots that could oxygen to peripheral soil. Consequently, the difference in different wetland plant was so obvious that efficiency in dechlorination of high-chlorinated biphenyls is not related to the length and width of roots.

Results of current study indicated the increase in PCB dechlorination through wetland plants, whereas maximum percentage of PCBs removal (approach 16\%) was closed with the tall fescue of Shen et al that percentage removal for highly chlorinated congeners added to $18 \%$ of all PCBs degradation under noamendment treatment (Shen et al. 2009).

These consequences may be attributed to support and stimulation of native bacterial species responsible for PCBs degradation in root zones also the capability of plants to degrade PCBs (Mackova et al. 2009). The actual amount biodiversity in root zone or soils may vary, associated with inadequate aqueous diffusion, change in organic matter amount and dissimilar soil texture (Chaudhry et al. 2005). According to the review about potential for phytoremediation of PCBs, another possibility is that plant-produced enzymes may be degrading the high chlorinated biphenyls to lower-chlorinated congeners (Zeeb et al. 2006).

There existed a certain extent of degradation, ignorant of total polychlorinated, high and low chlorinated biphenyls, under aerobic or anaerobic conditions. Various environmental factors affect the organic matter degradation i.e. aeration, temperature, nutrient availability, soil pH and temperature. Rise in temperature 
may cause decline in POPs concentration in soils and increase their degradation (DiVincenzo and Sparks 2001). Some other mechanisms for degradation of PCBs, do not involve microbes i.e. evaporation, chemical destruction and hydrophobic adsorption through organic matter (Ding et al. 2009).

\section{Conclusions}

Plant is an important remediation material in improving PCBs contaminated soils. However, this method only has high efficiency in removal of low chlorinated biphenyls, while low efficiency even nothing in removal of high components. In this study, we utilize wetland plants to dispose PCBs and screen most efficient plant. We first combine aerobic with anaerobic degradation procedure, which mainly devote to microbes and wetland plants. There into, plant providing excludes and anaerobic environment play critical role in all PCBs removal, which is objective of our study. There are numerous bio-chemical, morphological and physiological factors that play vital role in involvement of plant for PCBs degradation efficiency in all conditions.

Study also demonstrates that otherness in different wetland plant leads to different removal ability to all PCBs, high and low chlorinated biphenyls. In terms of gross PCBs loss, soils with wetland plants have more degradation ability, compared to two controls. The high chlorinated has same circumstance, while the low has a little difference. We get what we want to obtain by present experiment about wetland plant screening, which has meaningful effect on future research.

This study may not exactly explain the results under floody conditions. Moreover, reported variations could be due to certain experimental conditions i.e. immature wetland plants, contaminated soils and small unit size etc. Meanwhile, due to empirical nature of research studies the mechanisms elucidating alterations in removal among species generally remain unidentified. Inspite of all these limitations, we firmly believe that experimental species comparisons such as those studied here are important in screening for novel species or guiding species selection for a specific application.

\section{Declarations}

\section{Acknowledgments}

Special thanks are due to the Higher Education 664 Commission of Pakistan NRPU projects 7958 and 7964. Further thanks 665 are due to Pakistan Science Foundation project PSF/Res/CP/C-CUI/Envr 666 (151). Furthermore, thanks are due to Pakistan Academy of Sciences for 667 funding.

\section{Authors' contributions}

Foqia Khalid wrote paper, Muhammad Zaffar Hashmi review and supervised, Nadia Jamil wrote some parts of paper, Abdul Qadir wrote some parts of paper

\section{Funding}


Higher Education Commission of Pakistan NRPU projects 6757958 and 7964 . Thanks are due to Pakistan Science Foundation project 676 PSF/Res/CP/C-CUI/Envr (151) for providing the funding. Furthermore, 677 thanks are due to Pakistan Academy of Sciences for funding.

\section{Data availability}

Data is based on Lab and experimental work. Samples were collected and proper analysis and experiment was conducted and added results were obtained.

\section{Compliance with ethical standards}

\section{Competing of interests}

The authors declare that they have no competing interests.

\section{Ethical approval}

Not applicable

\section{Consent to participate}

Not applicable

\section{Consent to publish}

Not applicable

\section{References}

1. Abhilash, PC, Jamil S, Singh N (2009) Transgenic plants for enhanced biodegradation and phytoremediation of organic xenobiotics. Biotechnology advances, 27(4), 474-488. https://doi.org/10.1016/j.biotechadv.2009.04.002

2. Armstrong W, Armstrong J, Beckett P M (1990) Measurement and modelling of oxygen release from roots of Phragmites australis. In Constructed wetlands in water pollution control (pp. 41-51). Pergamon. https://doi.org/10.1016/B978-0-08-040784-5.50009-7

3. Asai K, Takagi K, Shimokawa M, Sue T, Hibi A (2002) Phytoaccumulation of coplanar PCBs by Arabidopsis thaliana. Environmental pollution (1987), 120(3), 509-511.

4. Balde CP, Forti V, Gray V, Kuehr R, Stegmann P (2017) The global e-waste monitor 2017: Quantities, flows and resources. United Nations University, International Telecommunication Union, and International Solid Waste Association.

5. Brix, H., (1987) Treatment of wastewater in the rhizosphere of wetland plants-the root-zone method. Wat. Sci. Tech. 19, 107-118. https://doi.org/10.2166/wst.1987.0193 
6. Campanella B F, Bock C, Schröder P (2002) Phytoremediation to increase the degradation of PCBs and PCDD/Fs. Environmental Science and Pollution Research, 9(1), 73-85.

7. Chaudhry Q, Blom-Zandstra M, Gupta S K, Joner E (2005) Utilising the synergy between plants and rhizosphere microorganisms to enhance breakdown of organic pollutants in the environment (15 pp). Environmental Science and Pollution Research, 12(1), 34-48.

8. Chekol T, Vough L R, Chaney RL (2004) Phytoremediation of polychlorinated biphenyl-contaminated soils: the rhizosphere effect. Environment international, 30(6), 799-804. https://doi.org/10.1016/j.envint.2004.01.008

9. Cheng XY, Chen WY, Gu B H, Liu X C, Chen F, Chen ZH, Chen Y J (2009) Morphology, ecology, and contaminant removal efficiency of eight wetland plants with differing root systems. Hydrobiologia, 623(1), 77-85.

10. Chu WK, Wong M H, Zhang J (2006b) Accumulation, distribution and transformation of DDT and PCBs by Phragmites australis and Oryza sativa L.: II. Enzyme study. Environmental Geochemistry and health, 28(1-2), 169-181. https://doi.org/10.1007/s10653-005-9028-7

11. Chu W K, Wong M H, Zhang J (2006a) Accumulation, distribution and transformation of DDT and PCBs by Phragmites australis and Oryza sativa L.: Il. Enzyme study. Environmental Geochemistry and health, 28(1-2), 169-181. https://doi.org/10.1007/s10653-005-9028-7

12. Cogliano V J, (1998) Assessing the cancer risk from environmental PCBs. Environmental health perspectives. 106 (6) 317-323 https://doi.org/10.1289/ehp.98106317

13. Cunningham SD, Anderson T A, Schwab AP, Hsu FC (1996) Phytoremediation of soils contaminated with organic pollutants. Advances in agronomy, 56(1), 55-114.

14. Di Lenola M, Barra Caracciolo A, Grenni P. (2018) Effects of apirolio addition and alfalfa and compost treatments on the natural microbial community of a historically PCB-contaminated soil. Water Air Soil Pollut. 229:143. doi.org/10.1007/s11270-018-3803-4. doi:10.1007/ s11270-018-38034

15. Ding, N., Guo, H., Hayat, T., Wu, Y., \& Xu, J. (2009). Microbial community structure changes during Aroclor 1242 degradation in the rhizosphere of ryegrass (Lolium multiflorum L.). FEMS microbiology ecology, 70(2), 305-314. https://doi.org/10.1111/j.1574-6941.2009.00742.x

16. Ding N, Hayat T, Wang J, Wang H, Liu X, Xu J (2011) Responses of microbial community in rhizosphere soils when ryegrass was subjected to stress from PCBs. Journal of Soils and Sediments, 11(8), 1355-1362. https://doi.org/10.1007/s11368-011-0412-x

17. DiVincenzo J, Sparks D, (2001) Sorption of the neutral and charged forms of pentachlorophenol on soil: Evidence for different mechanisms. Archives of Environmental Contamination and Toxicology. 40, 445-450. https://doi.org/10.1007/s002440010196

18. Doni S, Macci C, Peruzzi E, Arenella M, Ceccanti B, Masciandaro G (2012) In situ phytoremediation of a soil historically contaminated by metals, hydrocarbons and polychlorobiphenyls. Journal of Environmental Monitoring, 14(5), 1383-1390. 
19. Eapen S, Singh S, D'souza S F (2007) Advances in development of transgenic plants for remediation of xenobiotic pollutants. Biotechnology Advances, 25(5), 442-451.

https://doi.org/10.1016/j.biotechadv.2007.05.001

20. Master E R, Lai VWM, Kuipers B, Cullen W R, Mohn WW (2002) Sequential anaerobic- aerobic treatment of soil contaminated with weathered Aroclor 1260. Environmental science \& technology, 36(1), 100-103. https://doi.org/10.1021/es001930l

21. Epuri V, \& Sorensen DL (1997) Benzo (a) pyrene and hexachlorobiphenyl contaminated soil: phytoremediation potential. DOI: 10.1021/bk-1997-0664.ch015

22. Estime L, \& Rier Jr J P (2001) Disappearance of polychlorinated biphenyls (PCBs) when incubated with tissue cultures of different plant species. Bulletin of environmental contamination and toxicology, 66(5), 671-677. https://doi.org/10.1007/s001280061

23. Huesemann M H, Hausmann T S, Fortman T J, Thom R M, Cullinan V (2009) In situ phytoremediation of PAH-and PCB-contaminated marine sediments with eelgrass (Zostera marina). Ecological Engineering, 35(10), 1395-1404. https://doi.org/10.1016/j.ecoleng.2009.05.011

24. Imfeld G, Braeckevelt M, Kuschk P, Richnow H H (2009) Monitoring and assessing processes of organic chemicals removal in constructed wetlands. Chemosphere, 74(3), 349-362. https://doi.org/10.1016/j.chemosphere.2008.09.062

25. Schnoor J L, Light L A, McCutcheon SC, Wolfe NL, Carreia L H (1995) Phytoremediation of organic and nutrient contaminants. Environmental science \& technology, 29(7), 318A-323A. https://doi.org/10.1021/es00007a002

26. Jones RL (1994) ASPP recommends hazardous waste remediation technologies to DOE. ASPP Newsletter, 21(6), 12-13.

27. Kei CW (2004) Accumulation and Transformation of DDT and PCBs by Phragmites australisand Oryza sativa L (Doctoral dissertation, Hong Kong Baptist University).

28. Kurzawova V, Stursa P, Uhlik O, Norkova K, Strohalm M, Lipov J, Kochankova L, Mackova M. (2012) Plant-microorganism interactions in bioremediation of polychlorinated biphenyl-contaminated soil. $\mathrm{N}$ Biotechnol. 30(1):15-22. doi:10.1016/j.nbt.2012.06.004

29. Lai W L, Wang S Q, Peng C L, Chen Z H (2011) Root features related to plant growth and nutrient removal of 35 wetland plants. Water research, 45(13), 3941-3950. https://doi.org/10.1016/j.watres.2011.05.002

30. Liu H, Zhou Q, Wang Y, Zhang Q, Cai Z, Jiang G (2008) E-waste recycling induced polybrominated diphenyl ethers, polychlorinated biphenyls, polychlorinated dibenzo-p-dioxins and dibenzo-furans pollution in the ambient environment. Environment International, 34(1), 67-72. https://doi.org/10.1016/j.envint.2007.07.008

31. Liu J, Schnoor J L (2008) Uptake and translocation of lesser-chlorinated polychlorinated biphenyls (PCBs) in whole hybrid poplar plants after hydroponic exposure. Chemosphere, 73(10), 1608-1616. https://doi.org/10.1016/j.chemosphere.2008.08.009 
32. Mackova M, Macek T, Ocenaskova J, Burkhard J, Demnerova K, Pazlarova J (1997) Biodegradation of polychlorinated biphenyls by plant cells. International biodeterioration \& biodegradation, 39(4), 317-325. https://doi.org/10.1016/S0964-8305(97)00028-0

33. Mackova M, Prouzova P, Stursa P, Ryslava E, Uhlik O, Beranova K, Macek T (2009)

Phyto/rhizoremediation studies using long-term PCB-contaminated soil. Environmental Science and Pollution Research, 16(7), 817-829. https://doi.org/10.1007/s11356-009-0240-3

34. Mackova M, Uhlik O, Lovecka P, Viktorova J, Novakova M, Demnerova K, Macek T (2010) Bacterial degradation of polychlorinated biphenyls. In Geomicrobiology: molecular and environmental perspective (pp. 347-366). Springer, Dordrecht. https://doi.org/10.1007/978-90-481-9204-5_16

35. Mbemba KM, Kayath AC, Mabika AM, Mouko GD, Ouamba JM. Phytoremediation of industrial waste leachates by planted filters composed of Phragmites australis (Cav) Trin ex Steud, Typha latifolia L. and Cyperus papyrus L.

36. Meggo RE, Schnoor JL, Hu D. (2013) Dechlorination of PCBs in the rhizosphere of switchgrass and poplar. Environ Pollut. 178:312-321. doi:10.1016/j.envpol.2013.02.035

37. Meharg AA, Cairney JWG, (2000) Ectomycorrhizas-extending the capabilities of rhizosphere remediation? Soil Biology and Biochemistry. 32, 1475-1484. https://doi.org/10.1016/S00380717(00)00076-6

38. Molnar M, Leitgib L, Gruiz K, Fenyvesi E, Szaniszlo N, Szejtli J, Fava F (2005) Enhanced biodegradation of transformer oil in soils with cyclodextrin-from the laboratory to the field. Biodegradation, 16(2), 159-168. https://doi.org/10.1007/s10532-004-4873-0

39. Musilova L, Ridl J, Polivkova M, Macek T, Uhlik O. (2016) Effects of secondary plant metabolites on microbial populations: changes in community structure and metabolic activity in contaminated environments. IJMS. 17(8):1205. doi:10.3390/ijms17081205.

40. Paasivirta J, Sinkkonen S. (2009) Environmentally relevant properties of all 209 polychlorinated biphenyl congeners for modeling their fate in different natural and climatic conditions. J Chem Eng Data. 54(4):1189-1213. doi:10.1021/je800501h

41. Pavlikova D, Macek T, Mackova M, Pavlik M (2007) Monitoring native vegetation on a dumpsite of PCB-contaminated soil. International journal of phytoremediation, 9(1), 71-78. https://doi.org/10.1080/15226510601139433

42. Perigon S, Massier M, Germain J, Binet MN, Legay N, Mouhamadou B (2019) Metabolic adaptation of fungal strains in response to contamination by polychlorinated biphenyls. Environmental Science and Pollution Research, 26(15), 14943-14950. https://doi.org/10.1007/s11356-019-04701-5

43. Pezeshki S R (2001) Wetland plant responses to soil flooding. Environmental and Experimental Botany, 46(3), 299-312. https://doi.org/10.1016/S0098-8472(01)00107-1

44. Pino N J, Munera L M, Penuela G A (2019) Phytoremediation of soil contaminated with PCBs using different plants and their associated microbial communities. International journal of phytoremediation, 21(4), 316-324. https://doi.org/10.1080/15226514.2018.1524832 
45. Providenti M A, Lee H, Trevors J T (1993) Selected factors limiting the microbial degradation of recalcitrant compounds. Journal of industrial microbiology and biotechnology, 12(6), 379-395. https://doi.org/10.1007/BF01569669

46. Rovira A, (1959) Root excretions in relation to the rhizosphere effect. Plant and Soil. 11, 53-64. https://doi.org/10.1007/BF01394753

47. Salimizadeh M, Shirvani M, Shariatmadari H, Mortazavi M S (2020) Bentonite addition to a PCBcontaminated sandy soil improved the growth and phytoremediation efficiency of Zea mays $L$. and Alternanthera sessilis L. International Journal of Phytoremediation, 22(2), 176-183. https://doi.org/10.1080/15226514.2019.1652564

48. Salt, D. E., Smith, R. D., \& Raskin, I. (1998). Phytoremediation. Annual review of plant biology, 49(1), 643-668.

49. Scheringer M, Strempel S, Hukari S, Ng C A, Blepp M, Hungerbuhler K (2012) How many persistent organic pollutants should we expect?. Atmospheric Pollution Research, 3(4), 383-391. https://doi.org/10.5094/APR.2012.044

50. Schnoor J L, Licht L A, McCutcheon S C, Wolfe N L, Carreira L H (1995) Phytoremediation of contaminated soils and sediments. Environmental Science and Technology, 29(7), 318-323.

51. Shen C, Tang X, Cheema S A, Zhang C, Khan M I, Liang F, Chen Y (2009) Enhanced phytoremediation potential of polychlorinated biphenyl contaminated soil from e-waste recycling area in the presence of randomly methylated- $\beta$-cyclodextrins. Journal of hazardous materials, 172(2-3), 1671-1676. https://doi.org/10.1016/j.jhazmat.2009.08.064

52. Singer A C, Crowley D E, Thompson I P (2003) Secondary plant metabolites in phytoremediation and biotransformation. TRENDS in Biotechnology, 21(3), 123-130. https://doi.org/10.1016/S01677799(02)00041-0

53. Smith K E, Schwab A P, Banks M K (2008) Dissipation of PAHs in saturated, dredged sediments: a field trial. Chemosphere, 72(10), 1614-1619. https://doi.org/10.1016/j.chemosphere.2008.03.020

54. Song B, Xu P, Chen M, Tang W, Zeng G, Gong J, Ye S (2019) Using nanomaterials to facilitate the phytoremediation of contaminated soil. Critical reviews in environmental science and technology, 49(9), 791-824. https://doi.org/10.1080/10643389.2018.1558891

55. Stottmeister U, Wießner A, Kuschk P, Kappelmeyer U, Kästner M, Bederski O, Moormann H (2003) Effects of plants and microorganisms in constructed wetlands for wastewater treatment. Biotechnology advances, 22(1-2), 93-117. https://doi.org/10.1016/j.biotechadv.2003.08.010

56. Takahashi S, Tue N M, Takayanagi C, Suzuki G, Matsukami H, Viet P H, Tanabe S (2017) PCBs, PBDEs and dioxin-related compounds in floor dust from an informal end-of-life vehicle recycling site in northern Vietnam: contamination levels and implications for human exposure. Journal of Material Cycles and Waste Management, 19(4), 1333-1341. https://doi.org/10.1007/s10163-016-0571-3

57. Takai Y, Kamura T, (1966) The mechanism of reduction in waterlogged paddy soil. Folia microbiologica. 11, 304-313. https://doi.org/10.1007/BF02878902 
58. Teng Y, Li X, Chen T, Zhang M, Wang X, Li Z, Luo Y. (2016) Isolation of the PCB-degrading bacteria Mesorhizobium sp. ZY1 and its combined remediation with Astragalus sinicus L. for contaminated soil. Int J Phytoremediation. 18(2):141-149. doi:10.1080/ 15226514.2015.1073667.

https://doi.org/10.1080/15226514.2015.1073667

59. Tu C, Teng Y, Luo YM, Sun XH, Deng SP, Li ZG, Liu WX, Xu ZH. (2011) PCB removal, soil enzyme activities, and microbial community structures during the phytoremediation by alfalfa in field soils. $\mathrm{J}$ Soils Sediments. 11(4):649-656. doi:10.1007/s11368-011-0344-5

60. Van A, Correa PA, Schnoor JL. (2010) Phytoremediation of polychlorinated biphenyls: new trends and promises. Environ Sci Technol. 44(8):2767-2776. doi:10.1021/es902514d.

61. Vergani L, Mapelli F, Zanardini E, Terzaghi E, Di Guardo A, Morosini C, Raspa G, Borin S. (2017) Phytorhizoremediation of polychlorinated biphenyl contaminated soils: an outlook on plant-microbe beneficial interactions. Sci Total Environ. 575:1395-1406. doi: 10.1016/j.scitotenv.2016.09.218.

62. Vitale CM, Terzaghi E, Zati D, Di Guardo A. (2018) How good are the predictions of mobility of aged polychlorinated biphenyls (PCBs) in soil? Insights from a soil column experiment. Sci Total Environ. 645:865-875. doi:10.1016/j.scitotenv.2018.07.216

63. Wang Q, Cui Y, Dong Y (2002) Phytoremediation of polluted waters potentials and prospects of wetland plants. Acta Biotechnologica, 22(1-2), 199-208. https://doi.org/10.1002/15213846(200205)22:1/2<199::AID-ABI0199>3.0.CO;2-T

64. Wiegel J, Wu Q (2000) Microbial reductive dehalogenation of polychlorinated biphenyls. FEMS microbiology ecology, 32(1), 1-15.

65. Wießner A, Kappelmeyer U, Kuschk P, Kästner M (2005) Influence of the redox condition dynamics on the removal efficiency of a laboratory-scale constructed wetland. Water Research, 39(1), 248-256. https://doi.org/10.1016/j.watres.2004.08.032

66. Wischnak, C., Müller, R., (2008) Degradation of chlorinated compounds. Biotechnology Set, Second Edition. 241-271.

67. Wong M H, Wu S C, Deng W J, Yu X Z, Luo Q, Leung A O W, Wong A S (2007) Export of toxic chemicals-a review of the case of uncontrolled electronic-waste recycling. Environmental pollution, 149(2), 131-140. https://doi.org/10.1016/j.envpol.2007.01.044

68. Wu Z, Yuan W, Li J, Wang X, Liu L, Wang J (2017) A critical review on the recycling of copper and precious metals from waste printed circuit boards using hydrometallurgy. Frontiers of Environmental Science \& Engineering, 11(5), 8. https://doi.org/10.1007/s11783-017-0995-6

69. Xu L, Teng Y, Li Z-G, Norton JM, Luo YM. (2010) Enhanced removal of polychlorinated biphenyls from alfalfa rhizosphere soil in a field study: the impact of a rhizobial inoculum. Sci Total Environ. 408(5): 1007-1013. doi:10.1016/j.scitotenv.2009.11.031.

70. Yang Q, Chen Z H, Zhao J G, Gu B H (2007) Contaminant removal of domestic wastewater by constructed wetlands: effects of plant species. Journal of Integrative Plant Biology, 49(4), 437-446. https://doi.org/10.1111/j.1744-7909.2007.00389.x 
71. Zeeb B A, Amphlett J S, Rutter A, Reimer K J (2006) Potential for phytoremediation of polychlorinated biphenyl-(PCB)-contaminated soil. International journal of phytoremediation, 8(3), 199-221. https://doi.org/10.1080/15226510600846749

72. Zhao G, Wang Z, Dong M H, Rao K, Luo J, Wang D, Ma M (2008) PBBs, PBDEs, and PCBs levels in hair of residents around e-waste disassembly sites in Zhejiang Province, China, and their potential sources. Science of the Total Environment, 397(1-3), 46-57.

https://doi.org/10.1016/j.scitotenv.2008.03.010

73. Zhao G, Zhou H, Wang D, Zha J, Xu Y, Rao K, Wang Z (2009) PBBs, PBDEs, and PCBs in foods collected from e-waste disassembly sites and daily intake by local residents. Science of the total environment, 407(8), 2565-2575. https://doi.org/10.1016/j.scitotenv.2008.11.062

74. Zhao G, Xu Y, Han G, Ling B (2006) Biotransfer of persistent organic pollutants from a large site in China used for the disassembly of electronic and electrical waste. Environmental geochemistry and health, 28(4), 341-351. https://doi.org/10.1007/s10653-005-9003-3

\section{Figures}

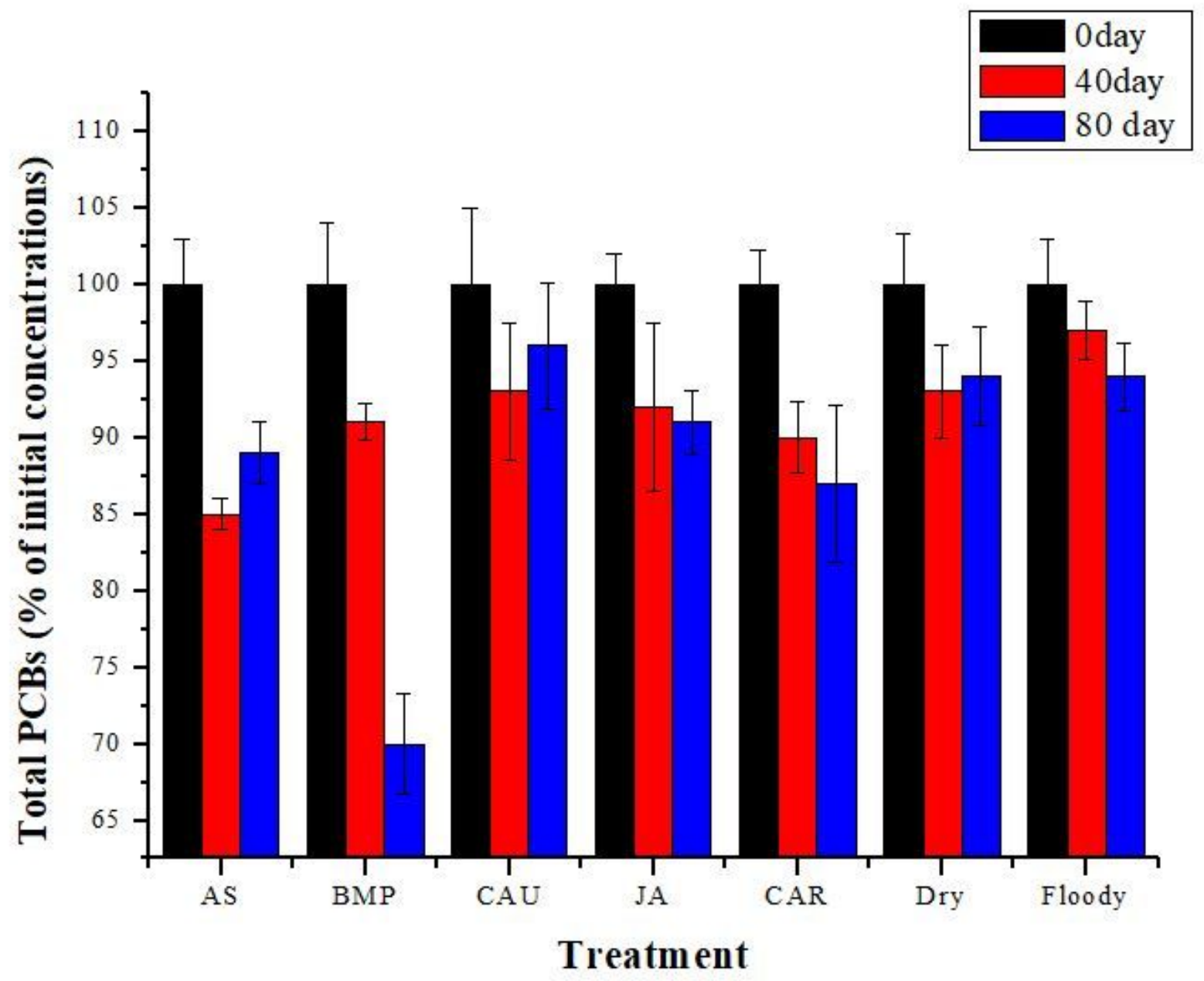

Figure 1 


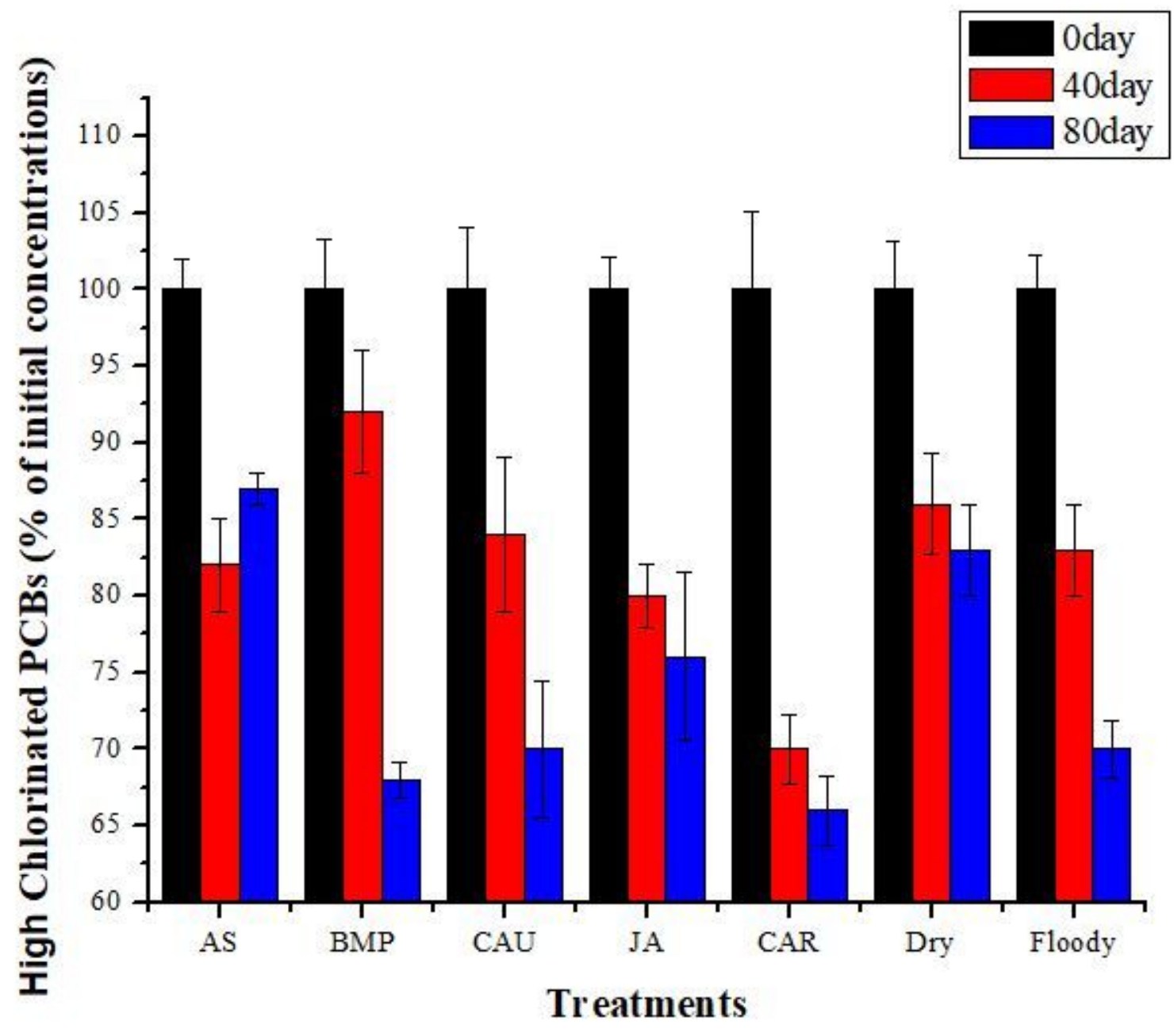

Figure 2

Removal efficiency of high chlorinated biphenyls in different treatments 


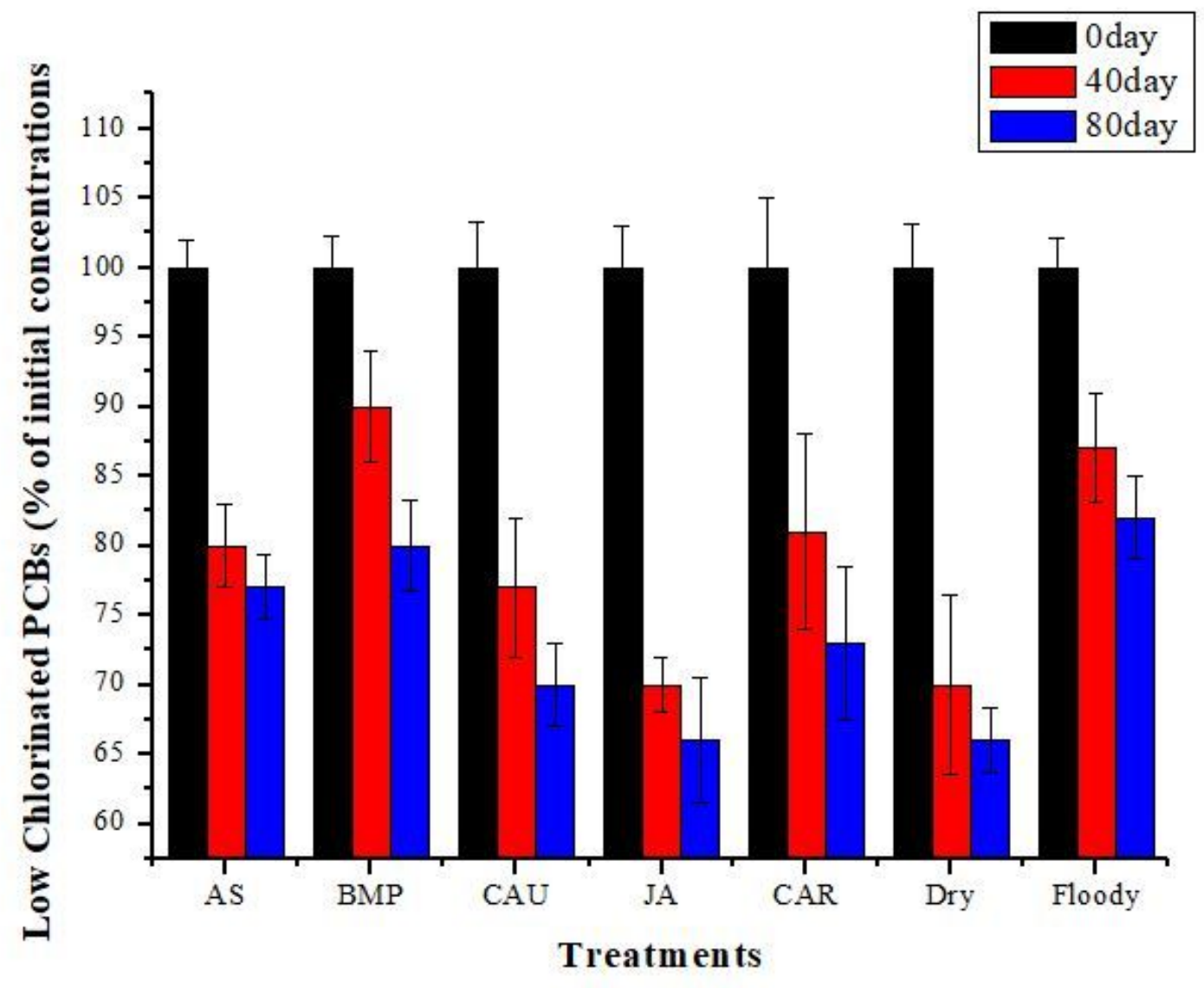

Figure 3

Removal efficiency of low chlorinated PCBs in different treatments 